\title{
Spontaneous Article
}

\section{Evaluation of active tectonics using geomorphic indices in a mountainous basin of Iran}

\section{Siamak BAHARVAND ${ }^{1 *} \odot$, Biswajeet PARDHAN ${ }^{2}$ and Salman SOORI ${ }^{3}$}

\author{
${ }^{1}$ Department of Geology, Islamic Azad University of Khorramabad, Khorramabad, Iran \\ ${ }^{2}$ Faculty of Engineering and Information Technology, University of Technology Sydney, Sydney, New South Wales, \\ Australia \\ ${ }^{3}$ Islamic Azad University of Khorram Abad, Young Researchers and Elite Club, Khorram Abad, Lorestan, Iran \\ *Corresponding author Email: s.baharvand@khoiau.ac.ir
}

\begin{abstract}
This study aims to evaluate the tectonic activities of the Vark basin, located in the great basin of Dez River in northwestern Iran, using geomorphologic indices combined with the geographical information system technique. Some geomorphic indices were used to achieve this aim. In this regard, the indices of stream length (SL), drainage asymmetry $\left(A_{f}\right)$, hypsometric integral $\left(H_{i}\right)$, valley floor ratio $\left(V_{f}\right)$, basin shape $\left(B_{s}\right)$, and mountain sinuosity $\left(S_{m f}\right)$ were estimated to reach an average index of relative tectonics $\left(I_{a t}\right)$, indicating the intensity classes of tectonic activity. The mean SL, $H_{i}, V_{f}$, and $B_{s}$ values were estimated as $2273,0.55,0.45$, and 1.75 , respectively, regarding the active class of tectonic activity. Therefore, considering the $A_{f}$ and $S_{m f}$ indices with values of 27 and 1.14, the basin was categorised as having semi-active conditions. The overall $I_{a t}$, with a value of 1.33 , represented the very high class $(1.0<$ $\left.I_{a t}<1.5\right)$ of tectonic activity. Hence, by calculating the index of relative active tectonics, the study area is observed as the intensive class concerning tectonic movements. Overall, the mean values of the $I_{a t}$ for all sub-basins were calculated as $1.50,1.17$, and 1.83 , revealing the very high and high classes of active tectonics in the basin. The results obtained on tectonic activity were further confirmed during field observations by examining the structurally complex joints, folds, slips, faults, and fractures of the area, which reflect the dynamic nature of the regional tectonics.
\end{abstract}

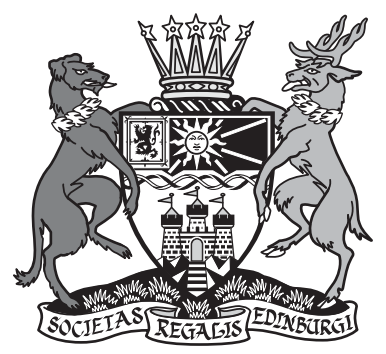

KEY WORDS: ArcGIS, Zagros Mountain, Quantitative Model, Geomorphology, Landform.

Tectonic geomorphology targets the rates of the dynamic process such as deformation, projection, erosion, etc. (Burbank \& Anderson 2001; Azor et al. 2002; Keller \& Pinter 2002; Bull 2007). Tectonic geomorphology relates to tectonics and geomorphologic processes (Burbank \& Anderson 2001), which can be categorised as characteristics indicating landform responses to active tectonics (Keller \& Pinter 2002; Chen et al. 2003). Tectonic studies involve active tectonics and neo-tectonics.

Active tectonics is formally defined as tectonic movement and is expected to occur within a future time concerning society (Wallace 1986), while neo-tectonics is the study of tectonic movement over a period ranging from the Neogene or Quaternary to the present (Wu \& Hu 2019). The application of geomorphic indices is a helpful way to analyse active tectonic subjects. These indices play an imperative role in understanding the essence of movements, as well as interpreting the regions' tectonic status. Among the quantitative and qualitative methods that are considered to investigate the active tectonics, quantitative assessment is essential for geosciences research to evaluate landforms using measurable indices (Lari et al. 2016).

Geomorphologic indices have been used to assess active tectonics in different regions of the world, such as the SE mountains of Spain (Silva et al. 2003), the Sierra Nevada mountain range of Spain (Perez-Pena et al. 2010), the Hindu Kush mountains of northern Pakistan (Mahmood \& Gloaguen 2012), the SW coast of India (Markose \& Jayappa 2013), central Anatolia in
Turkey (Yıldırım 2014), the Van basin in eastern Turkey (Selçuk 2016), the Himalayan basin in India (Dubey \& Satyam 2018), the northwestern coast of Algeria (Benbakhti et al. 2018), the Langshan mountains in northern China (He et al. 2018), and the Zagros mountains in northern Iraq (Obaid \& Allen 2017; Obaid \& Allen 2019; Zebari et al. 2019). For instance, Yildırım (2014) has noted that the geomorphic indices are compatible with the general relief of the mountain front and differential uplift along the fault zone of central Anatolia. In addition, Selçuk (2016) has reported that the geomorphic indices of mountain front sinuosity and valley morphology can reflect the highactivity tectonics along the fault lineaments of eastern Anatolia. Benbakhti et al. (2018), in a study on the coastal area of Algeria, revealed that elusive active tectonics characterised by geomorphic indices could aid in the evaluation of regional seismic hazards. An analysis by $\mathrm{He}$ et al. (2018) in northern China revealed that the quantitative geomorphologic indices could explain the disequilibrium landscape responding to active rock uplift and channel incision.

Due to its systematic structure and relevant results to assess tectonics sensitivity, many researchers have implicated this method in Iran, such as Dehbozorgi et al. (2010), Eynoddin et al. (2017), and Taromsari et al. (2018). Tectonically, Iran is an active region with massive historical earthquakes, which is located along the Alpine-Himalayan belt dividing the Eurasian from the Africa plates (Mansouri Daneshvar et al. 2018). 
Historically, Ambraseys \& Melville (1982) and Berberian (1994) have compiled a comprehensive historical catalogue for Iran earthquakes, revealing the destructive earthquakes over the last centuries (e.g., Bastam M7.2 in 1890 and Quchan M7.0 in 1893). Significantly dangerous earthquakes have recently stricken Iran, such as Saravan M7.8 in 2013 and Kermanshah M7.3 in 2017 (USGS 2018). Tectonic activity in Iran relates to elevation, volcanism, and active faults (Zamani et al. 2012). Hence, the mountainous basins are prone zones to active tectonics of Iran. In mountainous basins, active tectonics can be observed as contributing to up-down elevated topography resulting from tectonic and erosive processes (e.g., Andermann \& Gloaguen 2009; Bull 2009; Perez-Pena et al. 2009).

The Zagros mountains have active tectonics with a motion rate from $16 \mathrm{~mm}$ per year at the apex of the Arabian promontory to $26 \mathrm{~mm}$ per year in eastern Iran (Vernant et al. 2004; Allen \& Talebian 2011). The main part of landform deformation in the Zagros mountains is the fold-and-thrust belt (FTB), as a principal element in the Arabia-Eurasia continental collision (Allen \& Talebian 2011). From a topographic view, active thrust and reverse faulting is relatively confined to the lower relief in this region and strike-slip faulting affects the higher elevations (Talebian \& Jackson 2004). From a geologic view, the Zagros mountains are a great sedimentary basin with a wide range of carbonate-based rocks aged from the Jurassic to the Holocene (GSI 2015), including the geomorphic expression of the FTB deformed by a continental margin of the Arabian plate (Obaid \& Allen 2019).

Owing to the arid and semi-arid climate of Iran, the mountainous basins of Zagros are the hot spot of all the hazardous events, such as flash floods, landslides, and seismic-based phenomena. The prone zones in the mountainous basins of Iran are dominantly covered by failure features, which are triggered by their active tectonics. Hence, despite several local and regional studies regarding the geomorphologic landscape responses of the Zagros mountains to potential tectonics (e.g., Ramsey et al. 2008, Zebari \& Burberry 2015, Obaid \& Allen 2017, 2019), there is a wide potential to research the geomorphic and tectonic hazards. In this study, a geomorphologic procedure is used to assess the relative active tectonics of a mountainous basin in western Iran. For this purpose, some geomorphic indices in the Vark basin of the Zagros mountainous zone are measured using geographical information systems (GIS). Recently, scholars have broadly used the GIS technique through geomorphologic analyses and relative active tectonics (e.g., Harbor \& Gunnell 2007; Peters \& Van Balen 2007; Font et al. 2010; Ferraris et al. 2012; Markose \& Jayappa 2013).

\section{Study area}

The Vark basin, as the study area, has a total surface area of 140 $\mathrm{km}^{2}$ and is located between latitudes $\left[33^{\circ} 16^{\prime}-33^{\circ} 22^{\prime} \mathrm{N}\right]$ and longitudes $\left[48^{\circ} 29^{\prime}-48^{\circ} 39^{\prime} \mathrm{E}\right]$. It is one of the sub-basins of the Dez River Great Basin (with an area of $51,910 \mathrm{~km}^{2}$ ) at the northwestern part of Zagros, northwestern Iran (Fig. 1a). The topographical elevations vary from $900 \mathrm{~m}$ above sea level (m asl) in northern areas to $2800 \mathrm{~m}$ asl in southern areas, with an altitude of 1300-1600 m asl. Furthermore, the basin has a semiarid climate and, from 1950 to 2000, had an average annual temperature of $14^{\circ} \mathrm{C}$ and annual precipitation of $400 \mathrm{~mm}$ (Hijmans et al. 2005). Geologically, the study region in the Zagros FTB mainly consists of limestone and sandstone rocks aged from the late Cretaceous to the Palaeocene. The Zagros FTB is located along a section of the Arabian and Eurasian plates (Talebian \& Jackson 2004) and is characterised by numerous active anticlines atop of a basement fault (Zebari et al. 2019). The structurally complex joints, folds, slips, faults, and fractures reflect the dynamic nature of the regional tectonics. Geologically, the dominant trend of the fractures lies in the NW-SE direction, following the dominant trend of the region. Investigating the faults showed that there is a series of inverse and thrust faults through the Kashkan and Asmari formations in the $\mathrm{W}$ and $\mathrm{N}$ of the basin. These calcareous formation exposures, which dominantly cover the Vark basin, form a distinct topographic front within the Zagros, referred to as the mountain front fault (Allen et al. 2013), and are significantly susceptible to the seismicity.

\section{Data and methods}

\subsection{Data collection}

An excellent way to quickly assess active tectonics is the combination of geomorphic indices with GIS and other remotely sensed data. In this study, the geological data were extracted from source maps at the 1:100,000 scale via the Geological Survey of Iran (GSI 2015). Therefore, topographical layouts with a spatial resolution of $\sim 90 \mathrm{~m}$ were derived based on a Global Digital Elevation Model via National Aeronautics and Space Administration (NASA 2011) and were processed into ArcGIS ver. 10.4. In fieldwork, a handheld Trimble GeoXH geographical positioning system was used for general geomorphological investigation. In addition to the geological and topographical data and comprehensive field observations, satellite imagery data by ETM+ (Landsat 8) was used for a precise analysis of the study area via the US Geological Survey (USGS 2016).

\subsection{Methodology}

El Hamdouni et al. (2008) have demonstrated a method for the evaluation of active tectonics based on geomorphologic and topographic characteristics. According to this method and developed procedures by Mahmood \& Gloaguen (2012), Markose \& Jayappa 2013, and Elias et al. (2019), some layouts of geomorphologic indices including stream length (SL), drainage asymmetry $\left(A_{f}\right)$, hypsometric integral $\left(H_{i}\right)$, the ratio of valley floor $\left(V_{f}\right)$, basin shape $\left(B_{s}\right)$, and mountain sinuosity $\left(S_{m f}\right)$ were produced in this study. After the combination of the aforementioned layouts of indices in GIS, an integrated index of relative active tectonics $\left(I_{a t}\right)$ was estimated, divided into four intensity classes of very high $\left(1.0<I_{a t}<1.5\right)$, high $\left(1.5<I_{a t}<2.0\right)$, moderately $\left(2.0<I_{a t}<2.5\right)$ and relatively low $\left(I_{a t}>2.5\right)$ activity of tectonics.

2.2.1. SL. SL describes the topographic gradients in the length of the streams. This index was used to estimate the differential erosion of rocks (Hack 1973). It is calculated as the following equation:

$$
\mathrm{SL}=\frac{\Delta H}{\Delta L} \times L_{m}
$$

where SL is stream length index, $L m$ is the total length of trunk stream from the highest point in the upstream to the midpoint of the given basin, and $\Delta H / \Delta L$ is the slope of stream along the basin representing the elevation gradient $(\Delta H)$ with respect to length gradient of the basin $(\Delta L)$. When the streams flow along the region with active tectonics, then the values of the SL index will increase (Keller \& Pinter 2002). The SL values are determined using a digital elevation model (DEM) and GIS, indicating three classes of tectonic activity: $1=$ active (SL $>500), 2=$ semi-active $(300<\mathrm{SL}<500)$, and $3=$ inactive $(\mathrm{SL}<300)$ conditions.

2.2.2. $A_{f}$. $A_{f}$ evaluates the tectonic sloping/tilting of drainage basins (Hare $\&$ Gardner 1985). The $A_{f}$ is defined by the following equation:

$$
A_{f}=\frac{A_{r}}{A_{t}} \times 100
$$




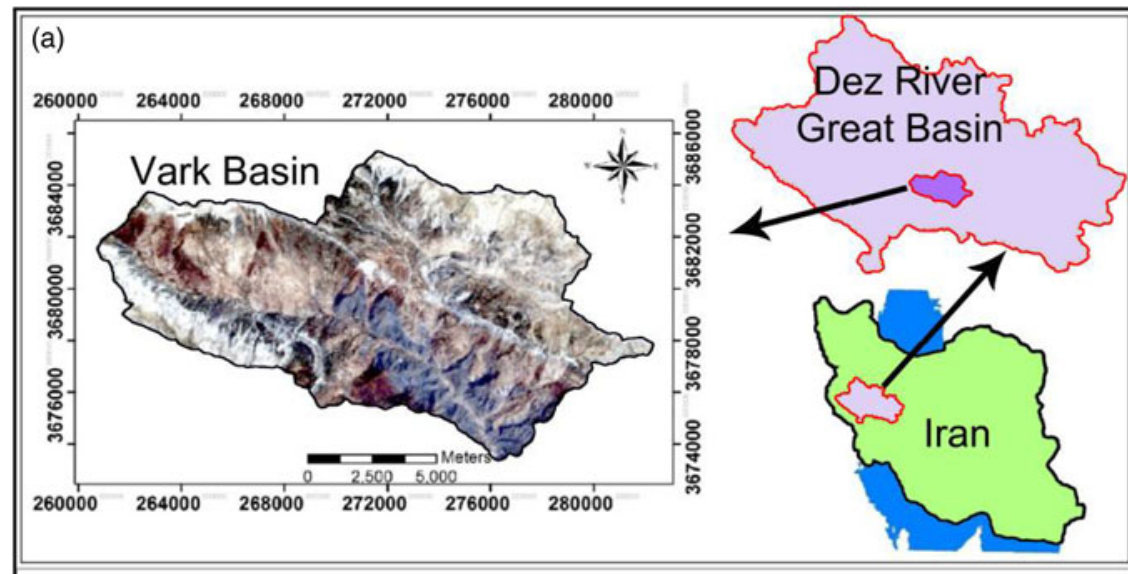

(b)

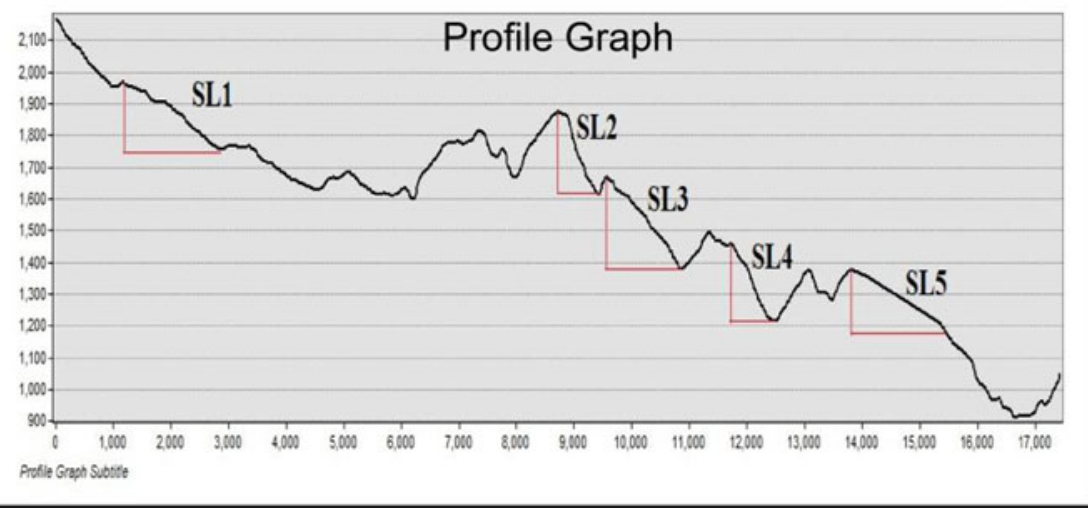

Figure 1 (a) Geographic position of the study area. (b) Length profile of the trunk stream to estimate the stream length index (SL).

where $A_{f}$ is drainage asymmetry, $A_{r}$ is an optional area defined as the right-hand area of the trunk stream facing downstream and $A_{t}$ is the total area of the basin. If the $A_{f}$ value is close to 50 , then drainage is under stable development with little or no steep slopes. An $A_{f}$ value above or below 50 indicates the sloping/tilting of the drainage basin affected by active tectonics and differential erosion (El Hamdouni et al. 2008). Its three classes of tectonic activity are categorised as $1=\operatorname{active}\left(A_{f}>75\right.$ or $\left.A_{f}<25\right)$, $2=$ semi-active $\left(25<A_{f}<45\right.$ or $\left.55<A_{f}<75\right)$, and $3=$ inactive $\left(45<A_{f}<55\right)$ conditions.

2.2.3. $\boldsymbol{H}_{\boldsymbol{i}}$. In the hypsometric curve, $H_{i}$ is defined as the area below the curve expressing the basin slopes without erosion (Mayer 1990). The $H_{i}$ is defined by the following equation (Pike \& Wilson 1971):

$$
H_{i}=\frac{E_{\text {mean }}-E_{\text {min }}}{E_{\max }-E_{\min }}
$$

where the elevation values of the mean $\left(E_{\text {mean }}\right)$, maximum $\left(E_{\text {max }}\right)$, and minimum $\left(E_{\text {min }}\right)$ in the basin are obtained from DEM. When a large part of the basin has a level higher than the mean elevation, then it will represent a youth stage of hypsometry and active tectonics. High values of the $H_{i}$ relate to the convex hypsometric curve $(>0.5)$, indicating the active class (1). Intermediate values are a straight curve $(0.4-0.5)$, indicating the semi-active class (2). Lower values $(<0.4)$ relate to a concave hypsometric curve, indicating the inactive class (3).

2.2.4. $V_{f} \quad V_{f}$ is discriminated between $V$-shaped and U-shaped flat-floored valleys (Bull \& McFadden 1977) and is used to identify the tectonically active fronts (Azor et al. 2002; Silva et al. 2003). It is defined by the following equation:

$$
V_{f}=\frac{2 V_{f w}}{E_{l d}+E_{r d}-2 E_{s c}}
$$

where $V_{f w}$ is the width of the valley floor across the stream, $E_{l d}$ and $E_{r d}$ are the elevations in the left and right valley divides, respectively, and $E_{s c}$ is the elevation in the surface of the valley floor. Deep V-shaped valley $\left(V_{f}<1\right)$ shows the active downcutting streams concerning active uplift, while flat-floored U-shaped valley $\left(V_{f}>1\right)$ shows achievement of the erosion in response to relative tectonic quiescence (Mahmood \& Gloaguen 2012). In this study, values of the $V_{f}$ index are determined from DEM, indicating three classes of tectonic activity: $1=$ active $\left(V_{f}<1\right), 2=$ semi-active $\left(1<V_{f}<2\right)$, and $3=$ inactive $\left(V_{f}>2\right)$ conditions.

2.2.5. $\boldsymbol{B}_{s}$. The horizontal extension of a drainage basin is described by the $B_{s}$ ratio (Ramirez-Herrera 1998), expressed by the following equation (Faghih et al. 2015):

$$
B_{s}=\frac{B_{l}}{B_{w}}
$$

where $B_{l}$ is the length of the basin from upstream to the outlet, and $B_{w}$ is the width of the basin across the widest point. The values of the $B_{s}$ index are categorised as $1=$ active $\left(B_{s}>4\right)$, $2=$ semi-active $\left(3<B_{s}<4\right)$, and $3=$ inactive $\left(B_{s}<3\right)$ conditions for relative tectonics.

2.2.6. $S_{\boldsymbol{m} \boldsymbol{f}}$ The $S_{m f}$ index demonstrates a balance between river slit processes and active tectonics forces over the mountain fronts (Bull \& McFadden 1977; Keller 1986). Bull (2007) has defined the $S_{m f}$ as the following equation (Taromsari et al. 2018):

$$
S_{m f}=\frac{L_{j}}{L_{s}}
$$

where $L_{j}$ is the aerial length of mountain front in the length of the mountain-piedmont joint, and $L_{s}$ is the overall length of the mountain front. An $S_{m f}$ values of less 3 or approximately 1 depend on steep mountain fronts. According to El Hamdouni 
Table 1 Detailed characteristics of $\Delta H, \Delta L$, and $L$ to estimate stream length index (SL).

\begin{tabular}{lcrrr}
\hline Section no. & $\Delta H(\mathrm{~m})$ & $\Delta L(\mathrm{~m})$ & $L(\mathrm{~m})$ & \multicolumn{1}{c}{ SL } \\
\hline 1 & 180 & 1550 & 2000 & 232 \\
2 & 250 & 800 & 9000 & 2812 \\
3 & 290 & 1300 & 10,200 & 2275 \\
4 & 240 & 700 & 12,000 & 4114 \\
5 & 210 & 1600 & 14,650 & 1922 \\
Mean & - & - & - & 2273 \\
\hline
\end{tabular}

et al. (2008), values of the $S_{m f}$ index are categorised into three classes: class 1 (active or very active) must be $S_{m f}<1.0$; class 2 (semi-active or moderately active) must be $S_{m f}=1.5-2.5$; and class 3 (inactive) must be $S_{m f}>2.5$.

2.2.7. $I_{a t}$. According to El Hamdouni et al. (2008), $I_{a t}$ is calculated by the average of geomorphic indices/values using the following equation:

$$
I_{a t}=\frac{S}{N}
$$

where $S$ represents the sum class values of all geomorphic indices, and $N$ is the number of indices, which is equal to six in the present study. $I_{a t}$ can be divided into four classes of intensity, representing very high $\left(1.0<I_{a t}<1.5\right)$, high $\left(1.5<I_{a t}<2.0\right)$, moderately $\left(2.0<I_{a t}<2.5\right)$, and relatively low $\left(I_{a t}>2.5\right)$ activity of local tectonics.

\section{Results and discussion}

\subsection{Geomorphic indices}

Geomorphic indices are considered as essential tools for determining tectonic activities in the active areas. In this study, a set of six indices ( $\mathrm{SL}, A_{f}, H_{i}, V_{f}, B_{s}$, and $S_{m f}$ ) were considered to investigate the $I_{a t}$ in a mountainous basin of Iran.

The SL index is sensitive to and dependent on the variations of the river's slope. However, this dependency and sensitivity can provide a benchmark and an estimation of the relationships that extend between the tectonic activities and the topography of the route (Molin et al. 2004). Accordingly, a modification in the river's slope or gradient can alter the SL as well. If the riverbed undergoes elevation and an increase in its height because of tectonic activity, the riverbed's slope would change accordingly, which would result in a change in the value of the SL index. The best technique to measure the SL is using the length profile of the trunk stream (Burbank \& Anderson 2001). In the study area, the SL values were calculated within five points along the trunk stream in the places where the profile slope changed (Fig. 1b). On average, the SL value was estimated as equal to 2273 (Table 1). Hence, the study area is classified as having an active class of tectonic activity.

$A_{f}$ can help to identify the tilting and asymmetry of the basin's tectonic activities. With a value of less than 50 , it is attributed to the left side (Fig. 2a). It can be noted that the difference between $A_{f}$ and 50 is used to describe the tectonics. A resultant size of this difference of more than 15 indicates tectonically active areas, while values between 7 and 15 refer to semi-active regions, and a value of less than 7 determines inactive regions (Keller \& Pinter 2002). In this research, the $A_{f}$ value was estimated as equal to 27 , which indicates a tectonically semi-active region and tilting on the basin's left side (geographically, in the N part).

The $H_{i}$ index can be used to study the relative changes of the height's ratio to the region. Based on morphometric results, the elevation values of the mean $\left(E_{\text {mean }}\right)$, maximum $\left(E_{\max }\right)$, and minimum $\left(E_{\min }\right)$ in the basin were obtained as 1950,2800 , and $900 \mathrm{~m}$ asl, respectively. Hence, the mean $H_{i}$ value for the whole basin was estimated as equal to 0.55 , indicating a convex shape and active tectonics. Also, Figure $2 \mathrm{~b}$ shows that the basin's

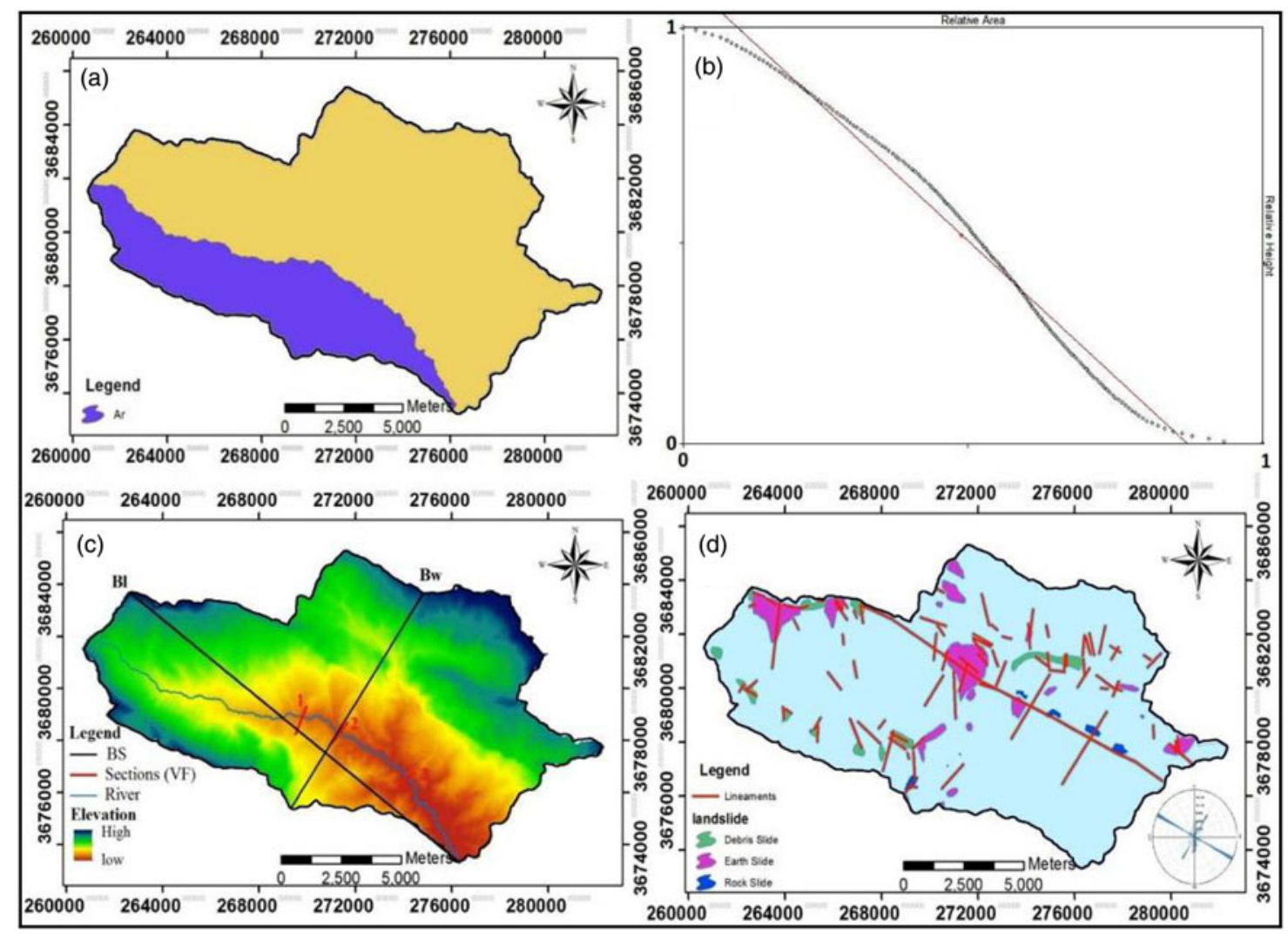

Figure 2 (a) Detailed characteristics of $A_{r}$ to estimate drainage asymmetry $\left(A_{f}\right)$. (b) Hypsometric curve of the study area. (c) Detailed characteristics to estimate the ratio of valley floor $\left(V_{f}\right)$ and index of basin shape $\left(B_{s}\right)$. (d) Distribution of fault lineaments and landslides in the study area. 
Table 2 Detailed characteristics of $E_{l d}, E_{r d}, E_{s c}$, and VFw to estimate ratio of valley floor $\left(V_{f}\right)$.

\begin{tabular}{lrrrrr}
\hline Section no. & $E_{l d}(\mathrm{~m})$ & $E_{r d}(\mathrm{~m})$ & $E_{s c}(\mathrm{~m})$ & $V_{f w}(\mathrm{~m})$ & $V_{f}$ \\
\hline 1 & 1440 & 1540 & 1230 & 150 & 0.57 \\
2 & 1415 & 1380 & 1150 & 70 & 0.28 \\
3 & 1240 & 1165 & 1020 & 100 & 0.54 \\
Mean & - & - & - & - & 0.45 \\
\hline
\end{tabular}

hypsometric curve is in a developing stage, which is considered as out of sequence maturity based on the underlying main recent fault (MRF) in the region. This corresponds to the results of Obaid \& Allen (2017) regarding the landscape maturity of various anticlines within the Zagros foothill zone.

Likewise, the convexity in the dimensionless hypsometric curve indicates that the tectonic activity of the basin dominates the erosion activities, while the curve denotes the dominance of the erosion activities over the neo-tectonic activity. According to this figure, it can be claimed that the basin is classified as having an active class of tectonic activity.

Three valleys were identified and selected along the basin's trunk stream to calculate the $V_{f}$ (Fig. 2c). Accordingly, by plotting the width profile of the valleys, the values of the maximum height of the two sides of the valley, the height of the valley floor, and, finally, the width of the valley were measured (Table 2). Therefore, the mean values of $V_{f w}, E_{l d}, E_{r d}$, and $E_{s c}$ were calculated as $105,1365,1360$, and $1130 \mathrm{~m}$, respectively, through the central valley along the trunk stream. Hence, the average $V_{f}$ index was obtained as 0.45 , indicating an active class of tectonic activity within the basin as a whole.

The index of $B_{s}$ reflects the notion that the shape of the stretched basin can be a signal of active tectonics. A reduction in tectonic activity followed by an arrest in elevation would, therefore, cause the erosion processes to gradually make the $B_{s}$ circular over time. In this research, by determining two parameters of $B_{l}(17.3 \mathrm{~km})$ and $B_{w}(9.9 \mathrm{~km})$, the $B_{s}$ index was estimated as equal to 1.75 , concerning inactive tectonic (Fig. 2c).

The index of $S_{m f}$ relates to equilibrium status between river slit processes and active tectonics. By observing the general pattern of trunk stream along the mountain's front of the basin, the possible stable condition of geomorphic evolution and semiequilibrium status can be concluded. Also, by calculating the characteristics of $S_{m f}$ (the aerial length of a mountain front of $L_{j}$ equal to $20,500 \mathrm{~m}$ and the overall length of the mountain front of $L_{s}$ equal to $17,900 \mathrm{~m}$ ), the index was estimated as being equal to 1.14 , which shows that the study area is classified as having a semi-active tectonic state.

Finally, the mean values of the aforementioned geomorphic characteristics and indices in the study area are represented in Table 3. The results presented in Table 3 represent the mean values of the geomorphic characteristics and indices in the study area, which are considered to classify $\left(I_{a t}\right)$. For this purpose, the activity class of all indices, as mentioned previously, was categorised to evaluate relative tectonic activity. Then, the mean value of the six classes was used to estimate the index and class of relative tectonic activity (Table 4). The results obtained from the calculation of the geomorphic indices and classes revealed a mean $I_{a t}$ value of 1.33 , indicating a very high class of active tectonics. This overall class can be a signal of active tectonics within the Vark basin in the future.

The detailed delineation of different sub-basins in the study area was considered to reveal which part of the basin is prone to having a very high class of active tectonics. In this regard, three sub-basins, entitled B1, B2, and B3, were derived in the Vark basin, with surface areas of 61,39 , and $40 \mathrm{~km}^{2}$, respectively. The $\mathrm{B} 1$ sub-basin includes the upstream region of the basin,
Table 3 Mean values of geomorphic characteristics and indices in the study area.

\begin{tabular}{llc}
\hline Geomorphic characteristics & Symbol & Value \\
\hline Total area of the basin $\left(\mathrm{km}^{2}\right)$ & $A_{t}$ & 140 \\
Perimeter of the basin $(\mathrm{km})$ & $P_{t}$ & 87 \\
Basin length (km) & $B_{l}$ & 17.3 \\
Basin width (km) & $B_{w}$ & 9.9 \\
Basin shape (-) & $B_{s}$ & 1.75 \\
Mean length of trunk stream (m) & $L m$ & 17,000 \\
Height gradient of trunk stream (m) & $\Delta H$ & 1190 \\
Length gradient of trunk stream (m) & $\Delta L$ & 8900 \\
Mean slope of the basin (\%) & $S_{t}$ & 7 \\
Stream length (-) & $S_{L}$ & 2273 \\
Optional area in right-hand area of trunk stream & $A_{r}$ & 38 \\
$\quad$ (km ${ }^{2}$ ) & & \\
Drainage asymmetry (-) & $A_{f}$ & 27 \\
Min. elevation of the basin (m) & $E_{m i n}$ & 900 \\
Max. elevation of the basin (m) & $E_{m a x}$ & 2800 \\
Mean elevation of the basin (m) & $E_{m e a n}$ & 1950 \\
Hypsometric integral (-) & $H_{i}$ & 0.55 \\
Elevation in the left divide of valley (m) & $E_{l d}$ & 1365 \\
Elevation in the right divide of valley (m) & $E_{r d}$ & 1360 \\
Elevation in the surface of valet floor (m) & $E_{s c}$ & 1130 \\
Valley floor width (m) & $V_{f w}$ & 105 \\
Valley floor ratio (-) & $V_{f}$ & 0.45 \\
Aerial length of a mountain front (m) & $L_{j}$ & 20,500 \\
Overall length of a mountain front (m) & $L_{s}$ & 17,900 \\
Mountain sinuosity (-) & $S_{m f}$ & 1.14 \\
\hline
\end{tabular}

while the B2 and B3 sub-basins are located in the middle and lowest parts of the basin. The mean values of the geomorphic indices and respective classes in these sub-basins are represented in Table 5. On this basis, the highest and lowest values of geomorphic indices within some parts of the study basin were calculated. The highest values of SL and $B_{s}$ indices (corresponding to the very high class of active tectonics) were recorded for subbasins B1 and B2, in the western and northern parts of the basin. Contrarily, the relatively lowest values of $A_{f}$ and $H_{i}$ indices were estimated for sub-basin B3 in the eastern part of the basin. The B3 sub-basin, located downstream in the study area, has a breadth shape with a lesser $V_{f}$. The $S_{m f}$ index was calculated as having moderate values corresponding to the second class of active tectonics. Overall, the mean values of the $I_{a t}$ index for all sub-basins were calculated as $1.50,1.17$, and 1.83 , revealing very high and high classes of active tectonics in the whole of the basin. Classification of the $I_{a t}$ index and active tectonics within the sub-basins of the study area are shown in Figure $3 \mathrm{a}$. The figure reveals that the sub-basin $\mathrm{B} 2$ is the most prone to active tectonics in the study area. This fact could be observed in its $H_{i}$ value $(0.58)$ - the highest value in the study area - expressing a very young stage of the geomorphologic process. In addition, the result of active tectonics in the study area can relate to the erosive carbonate lithology of the basin, with karstic

Table 4 Class values of indices and active tectonic index in the study area.

\begin{tabular}{llcl}
\hline Geomorphic characteristics & Symbol & Value & Class \\
\hline Stream length & $\mathrm{SL}$ & 2273 & 1 \\
Drainage asymmetry & $A_{f}$ & 27 & 2 \\
Hypsometric integral & $H_{i}$ & 0.55 & 1 \\
Valley floor ratio & $V_{f}$ & 0.45 & 1 \\
Basin shape & $B_{s}$ & 1.75 & 1 \\
Mountain sinuosity & $S_{m f}$ & 1.14 & 2 \\
Active tectonic index & $I_{a t}$ & - & 1.33 (very high) \\
\hline
\end{tabular}


Table 5 Mean values of geomorphic indices and classes of three sub-basins within the study area.

\begin{tabular}{|c|c|c|c|c|c|c|}
\hline \multirow[b]{2}{*}{ Geomorphic symbol } & \multicolumn{2}{|c|}{ Sub-basin B1 } & \multicolumn{2}{|c|}{ Sub-basin B2 } & \multicolumn{2}{|c|}{ Sub-basin B3 } \\
\hline & Value & Class & Value & Class & Value & Class \\
\hline$\overline{A_{t}}$ & 61 & - & 39 & - & 40 & - \\
\hline$P_{t}$ & 48 & - & 38 & - & 30 & - \\
\hline$B_{l}$ & 12.4 & - & 6.1 & - & 4.9 & - \\
\hline$B_{w}$ & 3 & - & 1.2 & - & 5.5 & - \\
\hline$B_{s}$ & 4.13 & 1 & 5.08 & 1 & 0.89 & 3 \\
\hline $\mathrm{Lm}$ & 12,100 & - & 5200 & - & 4900 & - \\
\hline$\Delta H$ & 650 & - & 390 & - & 150 & - \\
\hline$\Delta L$ & 4000 & - & 2000 & - & 1500 & - \\
\hline$S_{t}$ & 5 & - & 8 & - & 3 & - \\
\hline$S_{L}$ & 1966 & 1 & 1014 & 1 & 490 & 2 \\
\hline$A_{r}$ & 22 & - & 9 & - & 8 & - \\
\hline$A_{f}$ & 36 & 2 & 23 & 1 & 20 & 1 \\
\hline$E_{\min }$ & 1200 & - & 1200 & - & 900 & - \\
\hline$E_{\max }$ & 2800 & - & 2400 & - & 1200 & - \\
\hline$E_{\text {mean }}$ & 1900 & - & 1900 & - & 1050 & - \\
\hline$H_{i}$ & 0.44 & 2 & 0.58 & 1 & 0.50 & 1 \\
\hline$E_{l d}$ & 1420 & - & 1250 & - & 1100 & - \\
\hline$E_{r d}$ & 1410 & - & 1210 & - & 1100 & - \\
\hline$E_{s c}$ & 1300 & - & 1100 & - & 1020 & - \\
\hline$V_{f w}$ & 85 & - & 100 & - & 150 & - \\
\hline$V_{f}$ & 0.74 & 1 & 0.77 & 1 & 1.88 & 2 \\
\hline$L_{j}$ & 13,500 & - & 5800 & - & 5000 & - \\
\hline$L_{s}$ & 11,900 & - & 4900 & - & 4000 & - \\
\hline$S_{m f}$ & 1.13 & 2 & 1.18 & 2 & 1.25 & 2 \\
\hline$I_{a t}$ & - & 1.50 & - & 1.17 & - & 1.83 \\
\hline Active tectonics & - & High-very high & - & Very high & - & High \\
\hline
\end{tabular}

phenomena in the drainage system (Fig. 3b); it can also depend on the local and regional evidence of tectonics, such as the MRF in the Zagros mountains. Geographically, the northern segment of the MRF with a NW-SE direction corresponds to the whole of the basin (GSI 2015).

\subsection{Fieldwork observations}

The study of the structural status of morphotectonics, such as joints, folds, landslides, faults, and fractures, is essential in confirming the results of the geomorphic indices during the fieldwork. Depending on the carbonate and sandstone rocks and

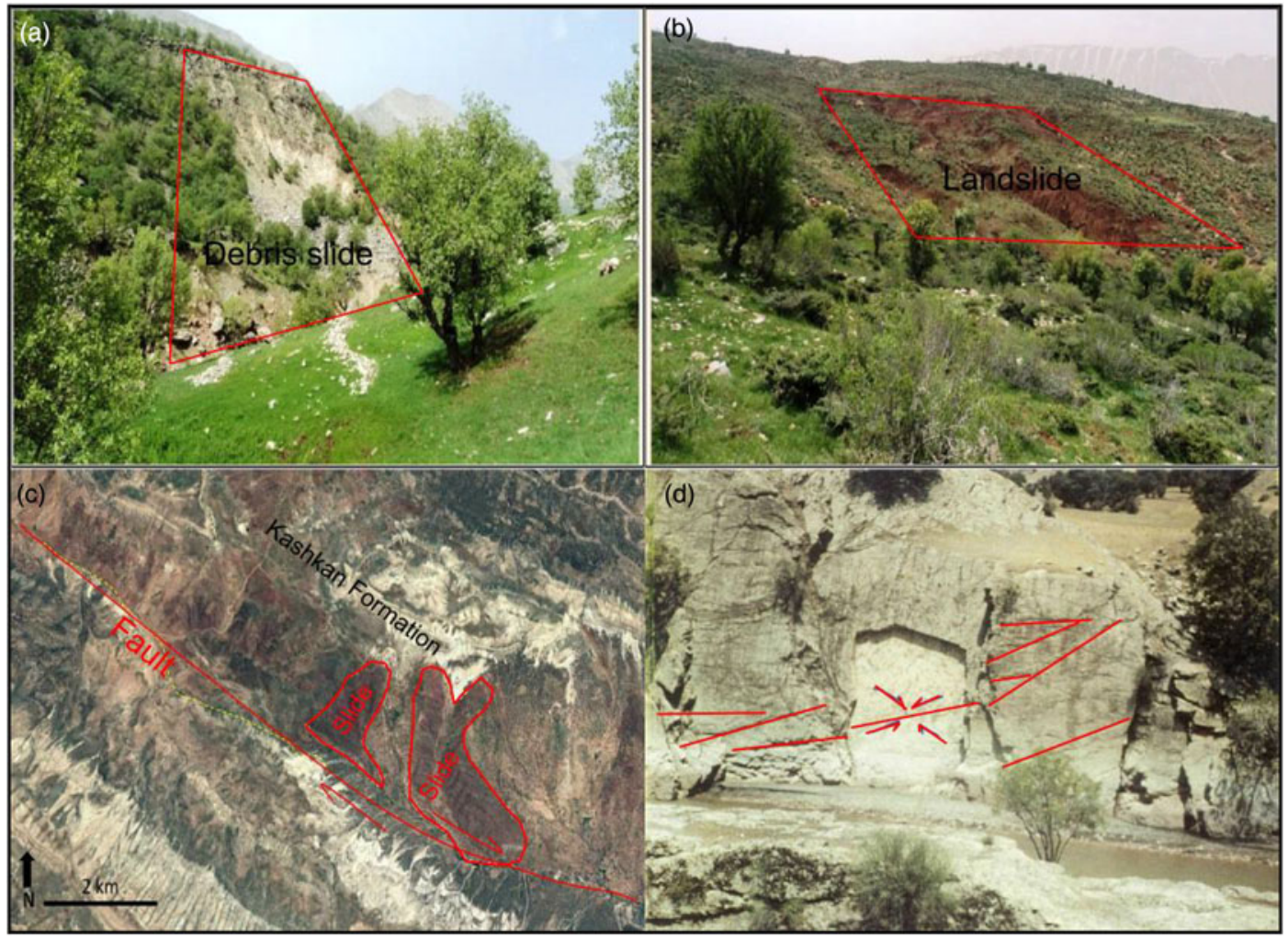

Figure 3 (a) General view of debris slide. (b) Landslide. (c) Inverse faults along the main riverbed of the study area. (d) Complex joints on a carbonate rock. 
tensions imposed on them, various deformations were observed in the basin, which results in the alternation of structures, related to the northern segment of the MRF. As mentioned in the literature, the MRF cuts through the low-angle thrusts and uplifts in the study area (Talebian \& Jackson 2002, 2004). The MRF is generally a prominent depression in topographic profiles across the Zagros mountains, caused by localised erosion along the steep fault trace, and the presence of folded structures (Allen et al. 2013). For instance, the folds in the basin have the direction of NW-SE and are aligned as regular anticlines and shallow synclines. The folds are affected by deep faults, which were observed as having an asymmetric pattern.

Therefore, using time series of satellite imageries, the prone zones of mass movements were surveyed in the basin. Field observations were performed to register landslides and mass movements. A landslide distribution map is presented in Figure 2d. According to a classification by Varnes (1978), landslides were categorised into three types of slides - some of these types are presented in Figures 4a, b. On this basis, more than 70\% of the study area is a susceptible zone regarding different types of landslides. Furthermore, by processing the satellite images, the fault lineaments in the study area are identified in Figure 2d. All lineaments that stretched along the whole basin were associated with the active tectonics, fractures, and faults that have the most distribution in the $\mathrm{N}$ part of the basin, corresponding to the sub-basin B2.

Several faults and fractures influenced a change in the landscape patterns and landslide occurrences. The main trend of faulting within the region was observed in the NW-SE direction, following the dominant physiographic trend of the basin, caused by the northern segment of MRF tectonics. The existence of inverse and thrust faults along the main riverbed of the basin,

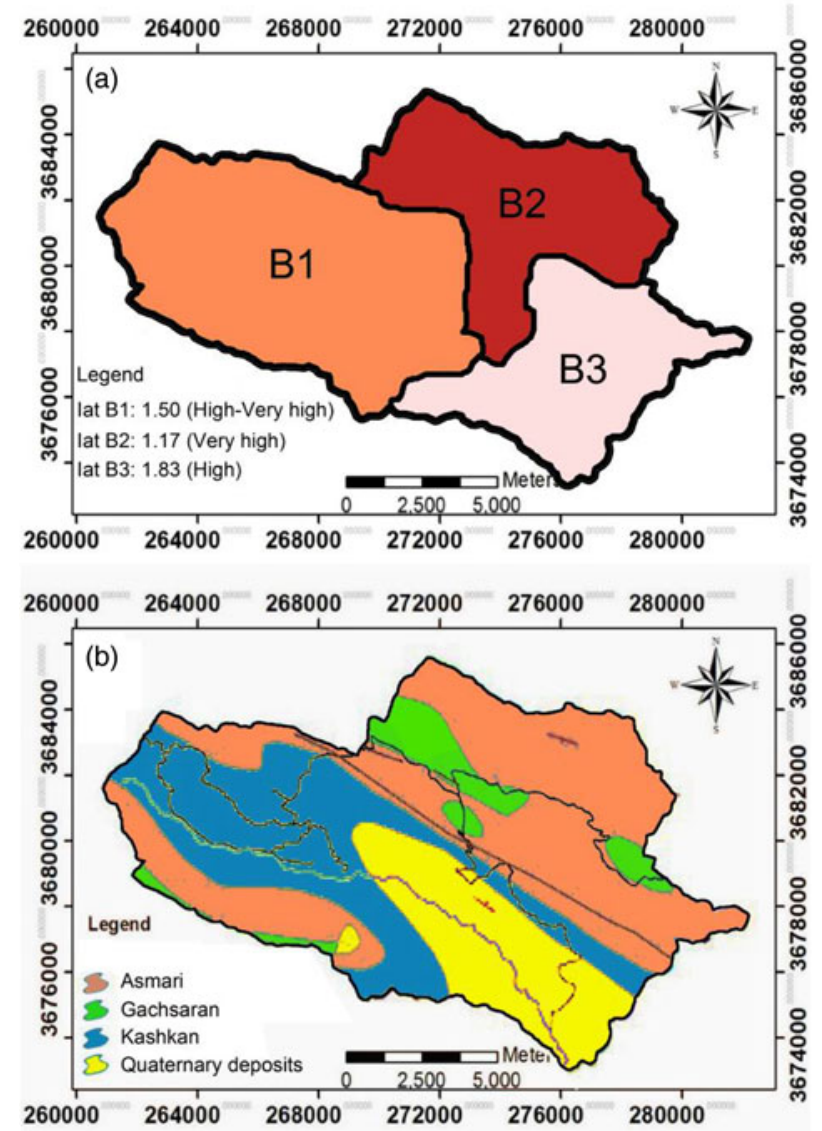

Figure 4 (a) Classification of Iat index and active tectonics within the sub-basins of the study area. (b) Geological units of the study area. aged to recent active tectonics in the Quaternary, indicated a pressure mechanism (Fig. 4c). Due to the tension and pressure occurring in the region, a set of shear, tensile, and complex joints have been produced in the study area, which can determine the tectonic activity, especially over the carbonate rocks (Fig. 4d). This can reveal that the local features are strongly linked to an underlying thrust fault, notable by the seismicity records in other researches (e.g., Allen et al. 2013).

\section{Conclusion}

This research attempted to investigate the tectonic activities in the Vark basin. This mountainous basin is located in the Zagros FTB in northwestern Iran. This study was the first practice to evaluate the tectonic activity in the Vark basin. For this purpose, several indices were utilised to study the tectonic activity of the Vark basin, including SL, $A_{f}, H_{i}, V_{f}, B_{s}$, and $S_{m f}$. By averaging the indices, as mentioned previously, the index of active tectonics $\left(I_{a t}\right)$ was obtained. The mean SL, $H_{i}, V_{f}$, and $B_{s}$ values were estimated as 2273, 0.55, 0.45, and 1.75 regarding the active class of tectonic activity, respectively. Therefore, considering the $A_{f}$ and $S_{m f}$ indices, the basin was categorised as having semi-active conditions. Following that, the overall index of $I_{a t}$ with a value of 1.33 represented the very high class of tectonic activity. In addition, the mean values of the $I_{a t}$ index for all sub-basins were calculated as $1.50,1.17$, and 1.83 , revealing the very high and high classes of active tectonics in the basin.

On average, the SL values were estimated as 1966, 1014, 490, and 2273 for sub-basins B1, B2, B3, and total basin, respectively; thus, the study area was classified as having an active class of tectonic activity. Investigating the basin's hypsometric curve and $H_{i}$ values $(0.44-0.58)$ indicated that the dominance of the tectonic activity could be categorised as erosive activities induced by the dynamic processes of geomorphology. The $V_{f}$ and $B_{s}$ values indicated a very high class of active tectonics in the whole of the basin, except the sub-basin B3. The B3 sub-basin in the downstream area of the study area has a breadth shape with a lesser $V_{f}$. Furthermore, the $A_{f}$ and $S_{m f}$ indices represent a relatively active condition in the basin. This can be related to the erosive carbonate lithology of the study area, with karstic phenomena in the drainage system.

Regarding $I_{a t}$, the Vark basin can be classified as having a very high class of active tectonics. Concerning the $I_{a t}$ values in the three sub-basins, this can be observed dominantly on the elevated parts and tilting terrain in sub-basin B2. Examination of the morphotectonic signals in the field observations showed that the study area has dynamically active tectonics.

\section{Acknowledgements}

The authors are grateful to the Islamic Azad University, Khorramabad Branch, which supported the present study as a research project. The authors are also very grateful to Dr Ahmed Kadhim Obaid (reviewer at Earth and Environmental Science Transactions of the Royal Society of Edinburgh) and the anonymous reviewers for contributing some essential comments and technical considerations to the manuscript.

\section{References}

Allen, M. B., Saville, C., Blanc, E. J. P., Talebian, M. \& Nissen, E. 2013. Orogenic plateau growth: expansion of the Turkish-Iranian Plateau across the Zagros fold-and-thrust belt. Tectonics 32, 171-90.

Allen, M. B. \& Talebian, M. 2011. Structural variation along the Zagros and the nature of the Dezful Embayment. Geological Magazine 148, 911-24.

Ambraseys, N. N. \& Melville, C. P. 1982. A history of Persian earthquakes. London: Cambridge University Press. 
Andermann, C. \& Gloaguen, R. 2009. Estimation of erosion in tectonically active orogenies. Example from the Bhotekoshi catchment, Himalaya (Nepal). International Journal of Remote Sensing 30, 3075-96.

Azor, A., Keller, E. A. \& Yeats, R. S. 2002. Geomorphic indicators of active fold growth: South Mountain-Oak Ridge Ventura basin, southern California. Geological Society of America Bulletin 114, 745-53.

Benbakhti, I. M., Maouche, S., Belhai, D., Harbi, A., Ritz, J. F., Rabai, G., Rezouk, A. \& Doumaz, F. 2018. Characterizing the active tectonics in the Oran region (Algeria) and recasting the 1790 earthquake. Journal of Seismology 22, 1549-61.

Berberian, M. 1994. Natural hazards and the first earthquake catalogue of Iran: Volume 1: historical hazards in Iran prior to 1900. AUNESCO/IIEES publication during UN/IDNDR, International Institute of Earthquake Engineering and Seismology, 603 pp.

Bull, W. B. 2007. Tectonic geomorphology of mountains: a new approach to paleoseismology. Oxford: Wiley, $328 \mathrm{pp}$.

Bull, W. B. 2009. Tectonically active landscapes. Chichester: WileyBlackwell, 326 pp.

Bull, W. B. \& McFadden, L. D. 1977. Tectonic geomorphology north and south of the Garlock fault, California. In Doehring, D. O. (ed.) Geomorphology in arid regions, 115-38. Proceedings of the Eighth Annual Geomorphology Symposium. Binghamton: State University of New York.

Burbank, D. W. \& Anderson, R. S. 2001. Tectonic geomorphology. Oxford: Blackwell Science, $247 \mathrm{pp}$

Chen, Y. C., Sung, Q. C. \& Cheng, K. Y. 2003. Along-strike variations of morphotectonic features in the western foothills of Taiwan: tectonic implications based on stream gradient and hypsometric analysis. Geomorphology 56, 109-37.

Dehbozorgi, M., Pourkermani, M., Arian, M., Matkan, A. A., Motamedi, H. \& Hosseiniasl, A. 2010. Quantitative analysis of relative tectonic activity in the Sarvestan area, central Zagros. Iran. Geomorphology 121, 329-41.

Dubey, R. K. \& Satyam, G. P. 2018. Morphotectonic appraisal of Yamuna river basin in headwater region: a relative active tectonics purview. Journal of the Geological Society of India 92, 346-56.

El Hamdouni, R., Irigaray, C., Fernandez, T., Chacon, J. \& Keller, E. A. 2008. Assessment of relative active tectonics. Southwest Boarder of Sierra Nevada (southern Spain). Geomorphology 96, 150-73.

Elias, Z., Sissakian, V. K. \& Al-Ansari, N. 2019. Assessment of the tectonic activity in northwestern part of the Zagros Mountains, northeastern Iraq by using geomorphic indices. Geotechnical and Geological Engineering 37, 3995-4007.

Eynoddin, E. H., Solgi, A., Pourkermani, M., Matkan, A. \& Arian, M. 2017. Assessment of relative active tectonics in the Bozgoush basin (SW of Caspian Sea). Open Journal of Marine Science 7, 211-37.

Faghih, A., Nourbakhsh, A. \& Kusky, T. M. 2015. GIS-based analysis of relative tectonic activity along the Kazerun fault zone, Zagros Mountains, Iran: insights from data mining of geomorphic data. Journal of Earth Science 26, 712-23.

Ferraris, F., Firpo, M. \& Pazzaglia, F. J. 2012. DEM analyses and morphotectonic interpretation: the Plio-Quaternary evolution of the eastern Ligurian Alps, Italy. Geomorphology 149-150, 27-40.

Font, M., Amorese, D. \& Lagarde, J. L. 2010. DEM And GIS analysis of the stream gradient index to evaluate effects of tectonics: the Normandy intra plate area (NW France). Geomorphology 119, 172-80.

GSI. 2015. Geological sheets at scale 1:100,000 archived by Geological Survey of Iran. http://www.gsi.ir. Accessed 2015.

Hack, J. T. 1973. Stream-profile analysis and stream-gradient index. Journal of Research of the U.S. Geological Survey 1, 421-29.

Harbor, D. \& Gunnell, Y. 2007. Along-strike escarpment heterogeneity of the Western Ghats: a synthesis of drainage and topography using digital morphometric tools. Journal of the Geological Society of India 70, 411-26.

Hare, P. W. \& Gardner, T. W. 1985. Geomorphic indicators of vertical neotectonism along converging plate margins, Nicoya Peninsula, Costa Rica. In Morisawa, M. \& Hack, J. T. (eds) Tectonic geomorphology, 123-34. Proceedings of the 15th Annual Binghamton Geomorphology Symposium. Boston, MA: Allen and Unw in.

He, C., Cheng, Y, Rao, G., Chen, P., Hu, J., Yu, Y. \& Yao, Q. 2018. Geomorphological signatures of the evolution of active normal faults along the Langshan Mountains, North China. Geodinamica Acta 30, 163-82.

Hijmans, R. J., Cameron, S. E., Parra, J. L., Jones, P. G. \& Jarvis, A. 2005. Very high resolution interpolated climate surfaces for global land areas. International Journal of Climatology 25, 1965-78.

Keller, E. A. 1986. Investigation of active tectonics: use of surficial earth processes. In Wallace, R. E. (ed.) Active tectonics, studies in geophysics, 136-47. Washington, DC: National Academy Press.
Keller, E. A. \& Pinter, N. 2002. Active tectonics: earthquakes uplift and landscape. Upper Saddle River, NJ: Prentice Hall, 362 pp.

Lari, A. A., Ansari, M. \& Ansari, S. 2016. Analysis neotectonic activities in Khafr basin. Open Journal of Geology 6, 484-97.

Mahmood, S. A. \& Gloaguen, R. 2012. Appraisal of active tectonics in Hindu Kush: insights from DEM derived geomorphic indices and drainage analysis. Geoscience Frontiers 3, 407-28.

Mansouri Daneshvar, M. R., Ebrahimi, M. \& Nejadsoleymani, H. 2018. Investigation of mining-induced earthquakes in Iran within a time window of 2006-2013. Journal of Seismology 22, 1437-1450.

Markose, V. J. \& Jayappa, K. S. 2013. A quantitative analysis of relative tectonic activity classes of Kali River basin, southwest coast of India. Arabian Journal of Geosciences 6, 4729-42.

Mayer, L. 1990. Introduction to quantitative geomorphology. Englewood, Cliffs, NJ: Prentice Hall.

Molin, P., Pazzaglia, F. J. \& Dramis, F. 2004. Geomorphic expression of active tectonics in a rapidly deforming Arc, Sila Massif, Calabria, Southern Italy. American Journal of Science 304, 559-89.

NASA. 2011. The Advanced Spaceborne Thermal Emission and Reflection Radiometer (ASTER) Global Digital Elevation Model (GDEM) archived by National Aeronautics and Space Administration (NASA). http://www.gdem.aster.ersdac.or.jp/search. jsp. Accessed 2011.

Obaid, A. K. \& Allen, M. B. 2017. Landscape maturity, fold growth sequence and structural style in the Kirkuk Embayment of the Zagros, northern Iraq. Tectonophysics 717, 27-40.

Obaid, A. K. \& Allen, M. B. 2019. Landscape expressions of tectonics in the Zagros fold-and-thrust belt. Tectonophysics 766, 20-30.

Perez-Pena, J. V., Azanon, J. M., Azor, A., Delgado, J. \& Gonzalez Lodeiro, F. 2009. Spatial analysis of stream power using GIS: SLk anomaly maps. Earth Surface Processes and Landforms 34, 16-25.

Perez-Pena, J. V., Azor, A., Azanon, J. M. \& Keller, E. A. 2010. Active tectonics in the Sierra Nevada (Betic Cordillera, SE Spain): insights from geomorphic indexes and drainage pattern analysis. Geomorphology 119, 74-87.

Peters, G. \& Van Balen, R. T. 2007. Tectonic geomorphology of the Upper Rhine Graben, Germany. Global and Planetary Change 58, 310-34.

Pike, R. J. \& Wilson S, E. 1971. Elevation-relief ratio, hypsometric integral, and geomorphic area-altitude analysis. Geological Society of America Bulletin 82, 1079-84.

Ramirez-Herrera, M. T. 1998. Geomorphic assessment of active tectonics in the Acambay graben, Mexican volcanic belt. Search Results Web Results Earth Surface Processes and Landforms 23, 317-32.

Ramsey, L. A., Walker, T. \& Jackson, J. 2008. Fold evolution and drainage development in the Zagros mountains of Fars province. SE Iran. Basin Research 20, 23-48.

Selçuk, A. S. 2016. Evaluation of the relative tectonic activity in the eastern Lake Van basin, East Turkey. Geomorphology 270, 9-21.

Silva, P. G., Goy, J. L., Zazo, C. \& Bardaji, T. 2003. Fault generated mountain fronts in Southeast Spain: geomorphologic assessment of tectonic and earthquake activity. Geomorphology 50, 203-26.

Talebian, M. \& Jackson, J. A. 2002. Offset on the main recent fault of NW Iran and implication for the late Cenozoic tectonics of the Arabia-Eurasia collision zone. Geophysical Journal International 150, 422-39.

Talebian, M. \& Jackson, J. A. 2004. A reappraisal of earthquake focal mechanisms and active shortening in the Zagros mountains of Iran. Geophysical Journal International 156, 506-26.

Taromsari, M. M., Dehbozorgi, M., Nozaem, R. \& Yassaghi, A. 2018 Active tectonics analysis of the Kalmard fault zone. Central Iran. Arabian Journal of Geosciences 11, 369.

USGS. 2016. Landsat 8 data products archived by United States Geological Survey. https://landsat.usgs.gov/landsat-8. Accessed 2016

USGS. 2018. Archive of significant earthquakes (2000-2018) archived by United States Geological Survey. https://earthquake.usgs.gov/earth quakes. Accessed 2018.

Varnes, D. J. 1978. Slope movements types and processes. National Academy of Sciences, Special Report, 11-33 pp. https://trid.trb.org/view/ 86168.

Vernant, P., Nilforoushan, F., Hatzfeld, D., Abbassi, M., Vigny, C., Masson, F., Nankali, H., Martinod, J., Ashtiani, A., Bayer, R., Tavakoli, F. \& Chery, J. 2004. Contemporary crustal deformation and plate kinematics in Middle East constrained by GPS measurements in Iran and northern Iran. Geophysical Journal International 157, 381-98.

Wallace, R. E. 1986. Overview and recommendations. In Wallace, R. E. (ed.) Studies in geophysics-active tectonics, 3-19. Washington, DC: National Academy Press. 
Wu, Z. \& Hu, M. 2019. Neotectonics, active tectonics and earthquake geology: terminology, applications and advances. Journal of Geodynamics 127, 1-15.

Yıldırım, C. 2014. Relative tectonic activity assessment of the Tuz Gölü Fault Zone; Central Anatolia, Turkey. Tectonophysics 630, 183-92.

Zamani, A., Sami, A. \& Khalili, M. 2012. Multivariate rule-based seismicity map of Iran: a data-driven model. Bulletin of Earthquake Engineering 10, 1667-83.
Zebari, M., Grützner, C., Navabpour, P. \& Ustaszewski, K. 2019. Relative timing of uplift along the Zagros Mountain Front Flexure (Kurdistan Region of Iraq): constrained by geomorphic indices and landscape evolution modeling. Solid Earth 10, 663-82.

Zebari, M. \& Burberry, C. M. 2015. 4-D Evolution of anticlines and implications for hydrocarbon exploration within the Zagros Fold-Thrust Belt, Kurdistan Region. Iraq. GeoArabia 20, $161-88$.

MS received 3 November 2019. Accepted for publication 2 March 2020. First published online 27 May 2020 